\title{
Pengaruh Biochar dan Residunya serta Umur Defoliasi Daun Jagung terhadap Keuntungan Hasil Jagung dan Beberapa Jenis Kacang Tipe Tegak Secara Salome di Lahan Kering
}

\author{
Syprianus Ceunfin ${ }^{a}$, Eduardus Yosef Neonbenia ${ }^{a}$ Jefrianus Ninoa, Yakobus Pffeferius Edvent Saba Agua, Magdalena Sunarty \\ Pareira $^{\mathrm{a}}$, Maximus Jefri Seran ${ }^{\mathrm{a}}$, Valeria Metkono ${ }^{\mathrm{a}}$ dan Maria Y. Biamnasi ${ }^{\mathrm{a}}$
}

a Peneliti Pusat Studi Lahan Kering, Universitas Timor, Kefamenanu, TTU - NTT, Indonesia, email: pslk_unimor@gmail.com

\section{Article Info}

\section{Article history:}

Received 31 Oktober 2019

Received in revised form 12 Desember 2019 Accepted 21 Januari 2020

DOI:

https://doi.org/10.32938/sc.v4i01.845

Keywords:

Biochar dan residunya

Jagung

Kacang tipe tegak

Tumpangsari Salome

Umur defoliasi

\section{Abstrak}

Masyarakat petani diwilayah Timor Barat kerap menggunakan pengetahuan lokal sebagai bagian dari warisan leluhur dalam sistem pertanian tradisional untuk meningkatkan ketahanan pangan rumah tangga keluarga, menggunakan sistem pengelolaan tanah dan tanaman, yang mana beberapa jenis tanaman pangan ditanam secara bersamaan waktu dalam satu lubang tanam yang sama (Salome). Penelitian ini bertujuan untuk membuktikan adanya efek biochar dan residunya serta umur defoliasi terhadap hasil Jagung dalam tumpangsari salome dengan beberapa jenis kacang di lahan kering dan untuk memperoleh jenis tanaman kacang yang cocok ditumpangsarikan secara salome dengan Jagung. Penelitian ini dilaksanakan pada bulan Juli 2018 sampai Juli 2019 di kebun percobaan Fakultas Pertanian, Universitas Timor, Kelurahan Sasi, Kecamatan Kota Kefamenanu, Kabupaten TTU. Penelitian ini dilaksanakan dalam tiga tahap penanaman yaitu tahap I: penanaman pada bulan Juli sampai November 2018. Tahap II: penanaman pada bulan November 2018 sampai Maret 2019. Penelitian ini menggunakan Rancangan Acak Kelompok (RAK) Faktorial 2 × 3 x 3 dengan 3 kali ulangan + monokultur jagung dan monokultur kacang. Faktor pertama: penggunaan biochar yang terdiri dari 2 aras yaitu tanpa biochar dan penggunaan biochar. Faktor kedua: umur defoliasi daun Jagung yang terdiri dari 3 aras yaitu tanpa defoliasi , Umur defoliasi 35 Hari Setelah Tanam, Umur defoliasi 75 HST. Faktor ketiga: jenis Kacang lokal tipe tegak yang terdiri dari 3 aras yaitu: Vigna radiata L. Vigna umbellata L., Phaseolus vulgaris L., sehingga terdapat 18 kombinasi. Hasil penelitian tahap I menunjukkan bahwa Berat biji tanaman jagung tertinggi dihasilkan kombinasi perlakuan tanpa biochar dengan umur defoliasi daun Jagung 35 hst pada sistem monokultur sedangkan pada sistem tumpang sari dihasilkan oleh kombinasi perlakuan biochar, umur defoliasi daun Jagung 35 hst pada jenis kacang Vigna radiata L., Hasil penelitian tahap II menunjukkan bahwa bahwa kombinasi perlakuan penggunaan residu biochar, umur defoliasi daun jagung 75 hst menghasilkan berat biji Jagung tertinggi yang ditanam dengan sistem tumpangsari dengan jenis kacang hijau. Hasil penelitian tahap I menunjukkan bahwa Berat biji tanaman kacang tertinggi dihasilkan oleh kombinasi perlakuan tanpa biochar dengan jenis kacang Phaseolus vulgaris L. pada sistem monokultur, sedangkan pada sistem tumpangsari dihasilkan oleh kombinasi perlakuan penggunaan biochar tanpa defoliasi daun Jagung dengan jenis kacang Phaseolus vulgaris L. Hasil penelitian tahap II menunjukkan bahwa bahwa kombinasi perlakuan penggunaan tanpa residu biochar, umur defoliasi daun Jagung 35 hst dengan jenis kacang hijau paling tinggi pada sistem tanam tumpangsari. Hasil Jagung pada sistem tumpangsari salome diawal penggunaan biochar mengalami penurunan dibandingkan kontrol tetapi meningkat kembali pada saat penggunaan residu biochar, umur defoliasi daun Jagung 35 hst lebih baik dibandingkan tanpa defoliasi, semua jenis kacang cocok untuk ditaman dengan sistem tumpangsari salome. Jenis kacang Vigna radiata L. dan Vigna umbellata L. lebih cocok ditanam dengan sistem tumpangsari salome dengan Jagung pada awal penggunaan biochar maupun pasa saat penggunaan residu biochar.

\section{Pendahuluan}

Pulau Timor dengan kondisi iklim tropis yang kering menyebabkan munculnya berbagai kearifan lokal sebagai bentuk adaptasi terhadap kondisi lingkungan. Di Timor Barat, para petani menggunakan pengetahuan lokal sebagai bagian dari warisan leluhur dalam sistem pertanian tradisional untuk meningkatkan ketahanan pangan rumah tangga keluarga. Diungkapkan Saba Agu, (2017) bahwa upaya pembangunan ekosistem lahan kering yang berkelanjutan di wilayah pulau Timor secara umum memerlukan intervensi intensif berdasarkan existing conductions pengelolaan lahan baik berupa pertimbangan aspek ekologi, sumberdaya lahan, sosial ekonomi, budaya (kearifan lokal) dalam ritus tani.

Salah satu bentuk kearifan lokal adalah sistem pengelolaan tanah dan tanaman yang mana beberapa jenis tanaman pangan ditanam secara bersamaan waktu dalam satu lubang tanam yang sama (Salome) (Levis et al., 2017) Salome (satu lobang rame-rame) merupakan ungkapan khusus untuk sistem tanam orang Timor barat yang menanam beberapa jenis tanaman pangan terutama jenis biji-bijian dalam lubang tanam yang sama, sehingga sistem Salome termasuk sistem tumpangsari. Sistem salome merupakan sistem tumpangsari spesifik wilayah karena hanya dilakukan diwilayan Timor Barat. Sistem ini cukup efektif untuk mensiasati perubahan iklim dalam kaitan mengantisipasi kegagalan panen. Petani percaya bahwa sistem 'salome' mampu meningkatkan standar ketahanan pangan.

Petani memiliki tiga motivasi untuk mempraktekkan 'Salome', yaitu sosial, ketahanan pangan dan ekonomis. Petani sangat puas dengan sistem 'Salome' dalam hal mengatasi kerawanan pangan (Levis et at, 2017). Keift (2007) menyatakan bahwa Petani di Timor memiliki keterampilan dan kapasitas untuk mengembangkan dan melestarikan varietas staples (varietas pokok bahan makanan) yang berbeda. Hal ini memungkinkan mereka menanam berbagai tanaman yang dapat mengatasi iklim yang keras dan tanah yang buruk. Hasil penelitian Ceunfin et al., (2018) Tumpangsari Salome antara tanaman jagung dan Vigna umbellata $\mathrm{L}$. menunjukkan hasil menguntungkan dimana menghasilkan nilai LER >1. Selanjutnya Ceunfin (2018), sistem tumpangsari Salome antara tanaman jagung dan vigna angularis $\mathrm{L}$. menghasilkan nilai LER $>1$ pada sistem Salome yang tidak berbeda nyata dengan sistem tumpangsari sela. Neo dan Ceunfin (2018), walaupun tanaman jagung dan kacang merupakan kombinasi terbaik tetapi harus memperhatikan tipe tajuk kacang terutama pada tipe tanaman kacang membelit karena akan menurunkan hasil jagung. Bau (2017) dan Humoen (2017), tumpangsari antara jagung dan vigna radiata $\mathrm{L}$. menunjukkan nilai LER $>1$. Sanit \& Nubatonis (2018), pendapatan bersih petani tumpangsari palawija sebesar RP 6.644.312,50 per musim tanam. Walaupun sistem tumpangsari salome memiliki berbagai keuntungan dan meningkatkan pendapatan petani seperti sistem tumpangsari pada umumnya tetapi tetap memiliki kekurangan-kekurangan yang harus diatasi. Masalah-masalah yang sering timbul adalah persaingan pada perakaran tanaman dalam memperoleh unsur hara dan air maupun persaingan ruang udara khususnya persaingan akan cahaya matahari. Selain persaingan kondisi lahan pertanian di Timor didominasi oleh tanah inceptisol yang minim akan unsur hara. Cara paling mudah untuk mempertahankan unsur hara didalam tanah adalah dengan menambahkan biochar sebagai pembenah tanah.

Biochar merupakan produk pirolisis yang dihasilkan dari proses pembakaran bahan baku dari limbah pertanian dengan suhu $300-600^{\circ} \mathrm{C}$ dengan suplai oksigen terbatas dan atau tanpa oksigen. Biochar berperan dalam perbaikan sifat fisik, kimia dan biologi tanah. Biochar memainkan peran lain sebagai tempat berkumpul dan rumah tinggal mikroorganisme terutama bakteri serta sebagai tandon hara. Biochar juga dapat digunakan untuk mengabsorpsi polutan seperti logam-logam berat (Uchimiya et al. 2012), mineral termasuk unsur-unsur hara di tanahtanah tropika yang daya ikat haranya rendah dan rentan terhadap pelindian hara (Venturaet al. 2012) serta dapat meningkatkan kapasitas tanah mengikat air (Novak et al. 2009). Hasil-hasil penelitian terbaru menunjukkan bahwa biochar dapat mengabsorpsi ammonium dan nitrat (Gai et al. 2014). Pencampuran biochar dan limbah cair ternak sapi perah selama 24 jam dapat meningkatkan kandungan $P$ sebesar 0,2148.4\%(Sarkhot et al2013). Aplikasi30 t/ha biochar pada lahan padang penggembalaan dapat menurunkan $70 \%$ emisi gas nitrogen oxide dan urin ruminan (Taghizadeh-Toosi el al. 2011). Penggunaan biochar kusambi pada tanah vertisol untuk budidaya tanaman selada mampu menurunkan berat segar trubus per tanaman maupun berat segar trubus per hektar hal ini karena biochar kusambi mampu meningkatkan $\mathrm{pH}$ tanah sampai pada angka diatas netral untuk tanaman selada. pHtanah yang tidak cocok bagi tanaman dapat menyebabkan tanaman tidak menampilkan pertumbuhan terbaiknya (Berek et al, 2017).

Glaser et al., (2001) menyatakan bahwa biochar mampu bertahan didalam tanah dalam waktu yang lama selama lebih dari ratusan tahun. Karena memiliki kemampuan bertahan lama didalam tanah maka diharapkan biochar mampu memperbaiki kerusakan sifat-sifat tanah seperti kerusakan fisik, kimia dan biologi tanah karena karbon didalam biochar lebih stabil (Steinbeisset al., 2009). Rosidiet al., (2016) menyatakan bahwa residu biochar batang tembakau memiliki pengaruh yang besar tehadap parameter $\mathrm{pH}, \mathrm{C}$ Organik dan N-Total Tanah, Jumlah daun dan Jumlah Biji tanaman kacang kedelai. Hal ini diperkuat oleh penelitian Niswati et al., (2018) bahwa pemberian residu biochar $5 \%$ kedalam tanah masih mampu meningkatkan 
kesuburan tanah dan tanaman jagung. Wijaya et al., (2018) bahwa residu biochar memberikan pengaruh yang berbeda nyata pada variabel tanah yaitu kadar C-Organik tanah, tinggi tanaman, jumlah daun dan berat brangkasan basah tanaman Selada.

Selain itu untuk menghindari kompetisi ruang udara dalam tumpangsari maka perlu teknologi sederhana yang bisa diterapkan yaitu dengan melakukan defoliasi daun untuk meningkatkan produksi tanaman baik tanaman utama maupun tanaman yang ditumpangsarikan. Hopkins (1995), Defoliasi adalah pemangkasan ujung batang. Defoliasi dimaksudkan untuk mengurangi saling menaungi antar tanaman maupun antara daun dalam tanaman yang bertujuan untuk meningkatkan penumpukan hasil fotosintesis pada bagian biji tanaman. Surtinah (2005), menyatakan produksi biji pada tanaman yang dipangkas $1 / 2$ bagian daun di atas tongkol lebih tinggi dibandingkan tanaman yang tidak dipangkas dengan pemberian pupuk urea yang sama. Selanjutnya Suchri (2010), menyatakan defoliasi daun jagung berpengaruh nyata terhadap pertumbuhan, hasil dan komponen hasil tanaman kacang tanah dalam tumpangsari.

Khodijahet al., (2014) menyatakan perlakuan defoliasi jagung memberikan pengaruh yang baik terhadap berat 100 biji pada tanaman kacang tanah dibandingkan dengan tanpa defoliasi, Sedangkan tanaman jagung, yang didefoliasi pada 1 dan 2 minggu setelah penyerbukan dapat meningkatkan jumlah tongkol/tanaman. Dengan dilakukannya defoliasi daun diharapkan dapat meningkatkan pertumbuhan dan hasil berbagai jenis kacang tipe tegak dalam tumpangsari. Tujuan dari penelitian ini adalah untuk membuktikan adanya efek biochar dan residunya serta umur defoliasi terhadap hasil jagung dalam tumpangsari salome dengan beberapa jenis kacang di lahan kering dan memperoleh jenis tanaman kacang yang cocok ditumpangsarikan secara Salome dengan jagung.

\section{Metode}

Penelitian ini dilaksanakan pada bulan Juli 2018 sampai Mare 2019 di kebun percobaan Fakultas Pertanian, Universitas Timor, Kelurahan Sasi, Kecamatan Kota Kefamenanu, Kabupaten TTU. Penelitian ini dilaksanakan dalam dua tahap penanaman yaitu tahap I: penanaman pada bulan Juli sampai November 2018 (Pengujian Biochar, Umur defoliasi daun Jagung dan jenis kacang pada tumpangsari salome), Tahap II adalah penanaman yang dilakukan pada bulan November 2018 sampai Maret 2019 (pengujian Residu Biochar, Umur defoliasi daun jagung dan jenis kacang pada tumpangsari salome). Penelitian ini menggunakan Rancangan Acak Kelompok (RAK) Faktorial 2 x 3 x 3 dengan 3 kali ulangan + monokultur jagung dan monokultur kacang. Faktor pertama adalah penggunaan biochar (B) yang terdiri dari 2 aras yaitu tanpa biochar (B0) dan penggunaan Biochar (B1). Faktor kedua adalah umur defoliasi daun jagung (D) yang terdiri dari 3 aras yaitu tanpa defoliasi (D0), Umur defoliasi 35 Hari Setelah Tanam (HST (D1)), Umur defoliasi 75 HST (D2). Faktor ketiga adalah jenis kacang lokal tipe tegak yang terdiri dari 3 aras yaitu: Vigna radiata L. (K1), Vigna umbellate L. (K2), Phaseolus vulgaris L. (K3), sehingga terdapat 18 kombinasi sehingga terdapat 54 unit penelitian, 12 unit monokultur kacang, 12 unit monokultur jagung.

Penanaman dilakukan dengan cara tradisional orang Timor yaitu sen bola mese atau menanam kedua jenis benih dalam lubang tanam yang sama (salome). Jarak tanam yang digunakan adalah jarak tanam standar $20 \mathrm{~cm} \times 70 \mathrm{~cm}$ pada tahap I dan tahap II. Panen jagung dilakukan dengan kriteria tongkol atau klobot sudah mengering, biji mengkilap, keras bila ditekan dengan kuku dan tidak membekas pada penelitian tahap I dan II sedangkan panen kacang dilakukan ketika polong kacang telah kering pada tahap penelitian I, II. Parameter yang diamati yakni:

\section{Berat Biji Tanaman Jagung dan Kacang Per Hektar}

Berat biji tanaman jagung maupun tanaman kacang dalam tumpangsari dihitung dengan cara mengkonversikan hasil tanaman per petak menjadi hektar

\section{Persentase Kehilangan Hasil Tanaman Jagung Dan Kacang}

Persentase kehilangan hasil tanaman jagung dan kacang akibat tumpangsari adalah jumlah hasil yang hilang akibat tumpangsari. Persenstase kehilangan hasil dapat dihitung dengan menggunakan rumus:

$$
K H=\frac{(h \text { monokultur tanaman } a-h \text { tumpangsari tanaman } a)}{\text { Hasil monokultur tanaman } a} \times 100 \%
$$

\section{Nilai Kesetaraan Lahan (NKL)}

Nilai Kesetaraan Lahan (LER: Land Equivalent Ratio) merupakan gambaran efisiensi penggunaan lahan yaitu jika nilai kesetaraan lahan $>1$ maka sistem tumpangsari itu menguntungkan. Nilai kesetaraan lahan dapat dihitung pada saat tanaman sudah dipanen. Perhitungan dilakukan pada hasil jagung intercropping (Yab), hasil jagung monocropping (Yaa), hasil kacang intercropping (Yba), dan hasil kacang monocropping (Ybb). Nisbah kesetaraan lahan dapat dihitung untuk mengetahui tingkat efisiensi lahan dalam sistem tumpangsari yang dicobakan. Menurut Beets (1982) NKL dapat dihitung dengan menggunakan rumus:

$$
\mathrm{NKL}=\frac{Y a b}{Y a a}+\frac{Y b a}{Y b b}
$$

\section{Land Equivalent Coefficient (LEC)}

Rasio kompetisi adalah rasio LER individu pada masing-masing komponen tanaman dengan memperhitukan proporsi tanaman yang telah ditanaman dalam tumpangsari pada awal penanaman (Yilmaz et al., 2015). Nilai rasio kompetisi dapat dihitung menggunakan rumus matematika (Palaniappan,1985) sebagai berikut:

$$
C R=\frac{Y a b / Y a a}{\mathrm{Yba} / \mathrm{Ybb}} \times \frac{\mathrm{Zba}}{\mathrm{Zab}} \text { atau } \frac{\mathrm{LER} \mathrm{a}}{\mathrm{LER} \mathrm{b}} \times \frac{\mathrm{Zba}}{\mathrm{Zab}}
$$

Dimana: hasil tanaman a dalam intercropping (Yab), hasil tanaman $b$ dalam intercropping ( $Y b a)$, hasil monocropping tanaman a (Yaa), hasil monocropping tanaman $b$ $(\mathrm{Ybb})$, Proporsi tanaman $b$ dalam intercropping $(\mathrm{Zba})$, proporsi tanaman a dalam intercropping $(\mathrm{Zab})$

\section{Competitive Racio (CR) / Rasio Kompetisi (RK)}

Kehilangan hasil aktual adalah proporsi kehilangan hasil atau keuntungan tanaman sela yang ditanaman secara tumpangsari bila dibandikan dengan masing-masing tanaman monokultur (Yilmaz et al, 2015). Kehilang hasil pada tumpangsari diakibatkan oleh adanya kompetisi terhadap sumberdaya yang dibutuhkan untuk memenuhi kebutuhan hidup tanaman. Nilai kehilangan hasil aktual dapat dicari menggunakan rumus matematika sebagai berikut (Banik ., 1996; Yilmaz et al., 2015):

$$
A Y L a b=(\mathrm{Yab} / \mathrm{Xab}) /(\mathrm{Yaa} / \mathrm{Xaa})-1
$$

Dimana: hasil tanaman a dalam intercropping (Yab), hasil monocropping tanaman a (Yaa), Proporsi tanaman a dalam intercropping (Xab), proporsi tanaman a dalam monokultur (Xaa)

\section{Hasil dan Pembahasan}

Hasil penelitian menunjukkan bahwa berat pipilan jagung yang ditanam pada saat perlakuan biochar lebih tinggi dari pada jagung yang ditanam pada saat menguji residu biochar dalam tumpangsari secara salome dengan beberapa jenis kacang (Gambar 1.) sedangkan tanaman berat biji kacang yang ditanam pada saat perlakuan biochar lebih rendah daripada hasil kacang yang ditanam pada saat menggunakan residu biochar dalam tumpangsari salome dengan jagung lokal Timor umur genjah (Gambar 1.). Hasil analisis anova menunjukkan bahwa parameter pengamatan terhadap berat kering pipilan jagung maupun kacang terjadi interaksi.

Hasil uji lanjut DMRT menunjukkan bahwa Berat pipilan jagung tertinggi dihasilkan oleh kombinasi tanpa biochar dengan umur defoliasi daun jagung 35 hst yang berbeda tidak nyata dengan kombinasi perlakuan tanpa biochar pada umur defoliasi 75 hst pada jagung monokultur tetapi berbeda sangat nyata dengan perlakuan lain baik dalam monokultur maupun tumpangsari pada saat menggunakan biochar, tetapi pada saat pengamatan jagung yang ditanam dengan menggunakan residu biochar, kombinasi perlakuan penggunaan residu biochar dengan umur defoliasi 75 hst dengan jenis kacang Vigna radiata L. menghasilkan berat pipilan jagung lebih tinggi yang berbeda sangat nyata dengan kombinasi perlakuan lainnya baik dalam tumpangsari maupun dalam monokultur (Tabel 1.). Hasil uji lanjut DMRT terhadap hasil biji kacang pada saat penggunaan biochar menunjukkan bahwa kombinasi perlakuan tanpa biochar dengan jenis kacang Phaseolus vulgaris L. pada sistem monokultur menghasilkan berat biji paling tinggi dan berbeda sangat nyata dengan semua kombinasi perlakuan lainnya, baik pada sistem monokultur maupun pada sistem tumpangsari, tetapi hasil kacang mengalami peningkatan yang sangat signifikan pada saat tanaman kacang menggunakan residu biochar dengan kombinasi perlakuan residu biochar dengan waktu defoliasi daun jagung 75 hst pada jenis kacang Vigna radiata L. yang berbeda sangat nyata dengan kombinasi perlakuan lainnya baik pada sistem monokultur maupun pada sistem tumpangsari (Tabel 1.)

Tabel 1. Pengaruh Perlakuan terhadap Hasil Tanaman Jagung dan Tanaman Kacang dalam Tumpangsari dan Monokultur (T/Ha)

\begin{tabular}{ccccc}
\hline \multirow{2}{*}{ Perlakuan } & \multicolumn{2}{c}{ Hasil Tanaman Tahap I } & \multicolumn{2}{c}{ Hasil Tanaman Tahap II } \\
\cline { 2 - 5 } & $\begin{array}{c}\text { Tumpangsari } \\
\text { Jagung }\end{array}$ & $\begin{array}{c}\text { Tumpangsari } \\
\text { Kacang }\end{array}$ & $\begin{array}{c}\text { Tumpangsari } \\
\text { Jagung }\end{array}$ & $\begin{array}{c}\text { Tumpangsari } \\
\text { Kacang }\end{array}$ \\
\hline B0D0K1 & $0.686 \mathrm{cdef}$ & $0.173 \mathrm{bcdefg}$ & $0.259 \mathrm{bc}$ & $0.744 \mathrm{a}$ \\
B0D0K2 & $0.449 \mathrm{def}$ & $0.174 \mathrm{abcdefg}$ & $0.322 \mathrm{bc}$ & $0.493 \mathrm{bcde}$ \\
B0D0K3 & $0.970 \mathrm{bc}$ & $0.195 \mathrm{bcdefg}$ & $0.404 \mathrm{abc}$ & $0.050 \mathrm{~h}$ \\
B0D1K1 & $0.811 \mathrm{bcdef}$ & $0.102 \mathrm{fg}$ & $0.376 \mathrm{abc}$ & $0.795 \mathrm{a}$ \\
B0D1K2 & $0.948 \mathrm{bcd}$ & $0.218 \mathrm{abcde}$ & $0.364 \mathrm{abc}$ & $0.567 \mathrm{abcd}$ \\
B0D1K3 & $0.460 \mathrm{def}$ & $0.197 \mathrm{abcdefg}$ & $0.390 \mathrm{abc}$ & $0.065 \mathrm{~h}$ \\
B0D2K1 & $0.542 \mathrm{cdef}$ & $0.110 \mathrm{defg}$ & $0.210 \mathrm{bc}$ & $0.708 \mathrm{ab}$ \\
B0D2K2 & $0.794 \mathrm{bcdef}$ & $0.154 \mathrm{cdefg}$ & $0.493 \mathrm{abc}$ & $0.374 \mathrm{defg}$ \\
B0D2K3 & $0.759 \mathrm{bcdef}$ & $0.214 \mathrm{abcde}$ & $0.404 \mathrm{abc}$ & $0.087 \mathrm{~h}$ \\
B1D0K1 & $0.581 \mathrm{cdef}$ & $0.210 \mathrm{abcdef}$ & $0.355 \mathrm{abc}$ & $0.670 \mathrm{abc}$ \\
B1D0K2 & $0.317 \mathrm{f}$ & $0.189 \mathrm{abcdefg}$ & $0.526 \mathrm{ab}$ & $0.223 \mathrm{fgh}$ \\
B1D0K3 & $0.658 \mathrm{cdef}$ & $0.272 \mathrm{ab}$ & $0.441 \mathrm{abc}$ & $0.066 \mathrm{~h}$ \\
B1D1K1 & $0.985 \mathrm{bc}$ & $0.171 \mathrm{bcdefg}$ & $0.441 \mathrm{abc}$ & $0.672 \mathrm{abc}$
\end{tabular}




\begin{tabular}{ccccc} 
B1D1K2 & 0.458 def & 0.149 cdefg & $0.429 \mathrm{abc}$ & $0.486 \mathrm{bcde}$ \\
B1D1K3 & $0.863 \mathrm{bcde}$ & $0.144 \mathrm{cdefg}$ & $0.441 \mathrm{abc}$ & $0.056 \mathrm{~h}$ \\
B1D2K1 & $0.606 \mathrm{cdef}$ & $0.090 \mathrm{~g}$ & $0.701 \mathrm{a}$ & $0.460 \mathrm{cdef}$ \\
B1D2K2 & $0.662 \mathrm{cdef}$ & $0.229 \mathrm{abc}$ & $0.369 \mathrm{abc}$ & $0.375 \mathrm{defg}$ \\
B1D2K3 & $0.439 \mathrm{ef}$ & $0.166 \mathrm{bcdefg}$ & $0.256 \mathrm{bc}$ & $0.091 \mathrm{~h}$ \\
\hline & \multicolumn{2}{c}{ Hasil Tanaman dengan Tahap I } & \multicolumn{2}{c}{ Hasil Tanaman Tahap II } \\
\cline { 2 - 5 } Perlakuan & Monokultur & Monokultur & Monokultur & Monokultur \\
& Jagung & Kacang & Jagung & Kacang \\
\hline B0D0 & 0.386 ef & - & $0.173 \mathrm{c}$ & - \\
B0D1 & $1.561 \mathrm{a}$ & - & $0.220 \mathrm{bc}$ & - \\
B0D2 & $1.437 \mathrm{a}$ & - & $0.213 \mathrm{bc}$ & - \\
B1D0 & $0.571 \mathrm{cdef}$ & - & $0.284 \mathrm{bc}$ & - \\
B1D1 & $0.742 \mathrm{bcdef}$ & - & $0.305 \mathrm{bc}$ & - \\
B1D2 & $1.191 \mathrm{ab}$ & - & $0.286 \mathrm{bc}$ & - \\
B0K1 & - & $0.108 \mathrm{efg}$ & - & $0.262 \mathrm{efgh}$ \\
B0K2 & - & $0.162 \mathrm{bcdefg}$ & - & $0.282 \mathrm{efgh}$ \\
B0K3 & - & $0.288 \mathrm{a}$ & - & $0.058 \mathrm{~h}$ \\
B1K1 & - & $0.086 \mathrm{~g}$ & - & $0.181 \mathrm{gh}$ \\
B1K2 & - & $0.221 \mathrm{abcd}$ & - & $0.383 \mathrm{defg}$ \\
B1K3 & - & $0.237 \mathrm{abc}$ & - & $0.079 \mathrm{~h}$ \\
\hline Interaksi & + & $(+)$ & $(+)$ & $(+)$
\end{tabular}

Keterangan: Huruf yang diikuti dengan huruf sama pada kolom sama berbeda tidak nyata pada uji lanjut DMRT a 0,05., (+): Terjadi interaksi kombinasi perlakuan., B0: tanpa biochar, B1: Biochar sekam Padi, D0: Tanpa Defoliasi, D1: Defoliasi daun jagung pada umur 35 hst, D2: Defoliasi daun jagung pada umur 75 hst, K1: jenis Kacang Vigna radiata L., K2: Jenis Kacang Vigna umbellata L., K3: jenis kacang Phaseolus vulgaris L.

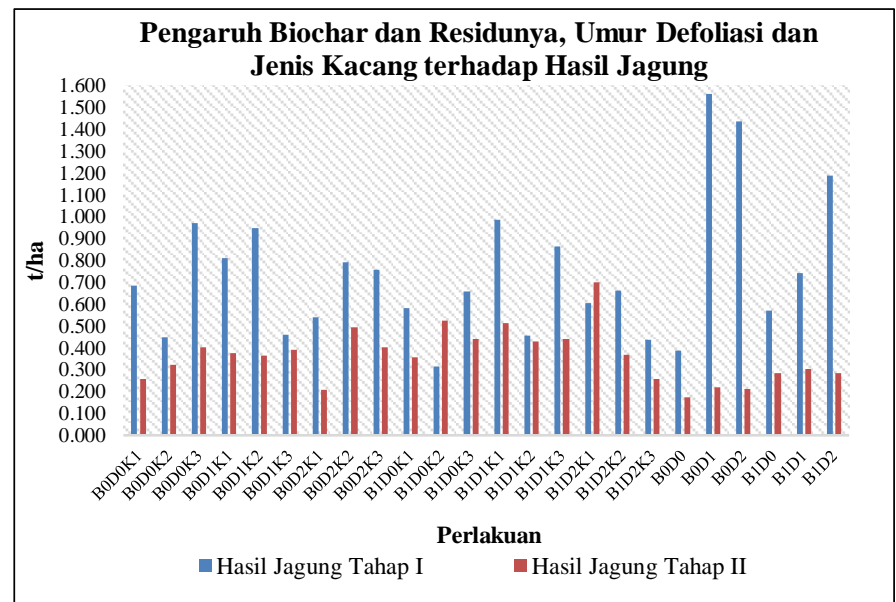

Gambar 1. Grafik Berat Pipilan Jagung ; B0: tanpa biochar, B1: Biochar sekam Padi, D0: Tanpa Defoliasi, D1: Defoliasi daunjagung pada umur 35 hst, D2: Defoliasi daun jagung pada umur 75 hst, K1: jenis Kacang Vigna radiata L., K2: Jenis Kacang Vigna Umbellata L., K3: jenis kacang Phaseolus vulgaris $\mathrm{L}$

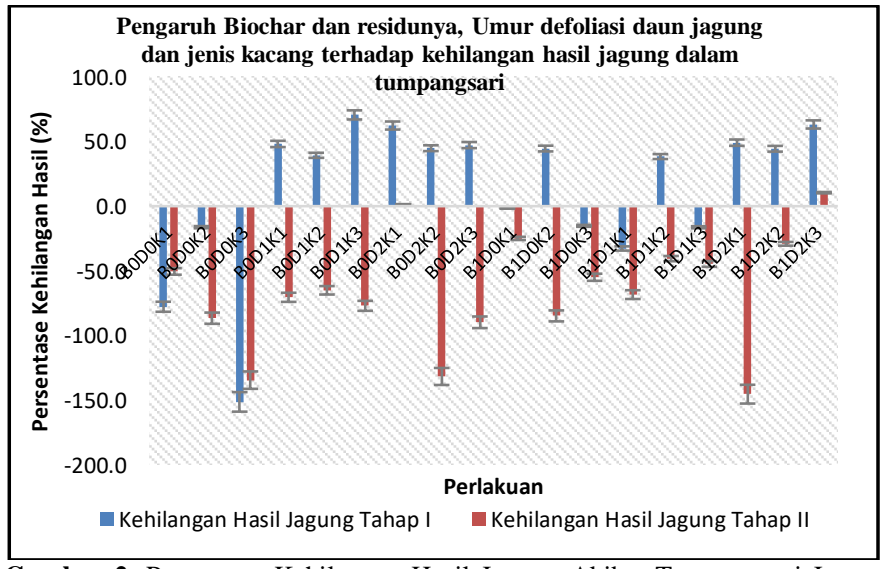

Gambar 2. Persentase Kehilangan Hasil Jagung Akibat Tumpangsari Jagung dengan Kacang ; B0: tanpa biochar, B1: Biochar sekam Padi, D0: Tanpa Defoliasi, D1: Defoliasi daun jagungpada umur 35 hst, D2: Defoliasi daun jagung pada umur 75 hst, K1: jenis Kacang Vigna radiata L., K2: Jenis Kacang Vigna umbellata L., K3: jenis kacang Phaseolus vulgaris $\mathrm{L}$.

Hasil Jagung dalam (Gambar 1). menunjukkan bahwa tanaman Jagung yang ditumpangsarikan dengan kacang menghasilkan berat pipilan Jagung lebih tinggi pada saat penanaman dengan menggunakan biochar dan menurun pada saat tanaman jagung yang ditanam dengan menggunakan residu biochar. Hal ini sebagai akibat dari konversi unsur hara yang disumbangkan oleh tanaman kacang baik pada saat kacang masih tumbuh maupun sudah mati melalui bintil akar dan serasah kacang. Kacang memiliki kemampuan memfiksasi nitrogen bebas didalam bintil akar oleh bakteri penambat nitrogen.
Bintil akar yang sudah tua dan luruh hancur didalam tanah meninggalkan unsur-unsur hara dan bakteri yang mungkin diikat didalam tanah oleh biochar pada musim tanam pertama kemudian unsur hara dan bakteri dimanfaatkan lagi oleh tanaman pada saat musim tanam berikutnya. Indra dewa et al., (2004) menyatakan bahwa gas nitrogen dari udara maupun nitrogen anorganik dari dalam tanah dalam bentuk ion ammonium dan nitrat dapat dimanfaatkan oleh tanaman legume melalui bintil akar.

Tumpangsari sering mengalami kompetisi yang mengakibatkan penurunan hasil tanaman baik tanaman utama maupun tanaman sisipan. Hasil penelitian ini menunjukkan bahwa terjadi penurunan hasil jagung baik pada awal penggunaan biochar maupun residunya. Penurunan hasil jagung pada awal penggunaan residu berkisar antara $-151,3 \%$ sampai $+70,6 \%$. Penurunan berat pipilan jagung $-151,3 \%$ menunjukkan adanya peningkatan hasil sebesar $151,3 \%$ dari monokultur sedangkan penurunan hasil $+70,6 \%$ menunjukkan adanya kehilangan hasil akibat tumpangsari sebanyak 70,6\% dari monokultur. Jagung yang ditanam bersama jenis kacang Vigna radiata L. mengalami kehilangan hasil sebesar $-77,8 \%$ sampai $+62,3 \%$ pada awal penggunaan biochar sedangkan pada penggunaan residu biochar terjadi kehilangan hasil sebesar $-145,4 \%$ sampai $+1,5 \%$ dibandingkan dengan monokulturnya. Jagung yang ditanam bersama jenis kacang Vigna umbellata L. mengalami kehilangan hasil sebesar $-16,2 \%$ sampai $+44,8 \%$ pada awal penggunaan biochar sedangkan pada penggunaan residu biochar tanaman jagung mengalami kehilangan hasil sebesar $-131,7 \%$ sampai $-29,1 \%$. Jagung yang ditanam bersama jenis kacang Phaseolus vulgaris L. mengalami kehilangan hasil sebesar $-151,3 \%$ sampai $+70,6 \%$ pada awal penggunaan biochar dan $-134,5 \%$ sampai $+10,4 \%$ pada saat penggunaan residu biochar (Gambar 2.). Hal ini senada dengan ungkapan Sundari et al., (2019) bahwa kehilangan hasil akibat tumpangsari pada hasil jagung berkisar $25,78 \%$ sampai $41,06 \%$ yang ditumpangsarikan dengan kacang kedelai.

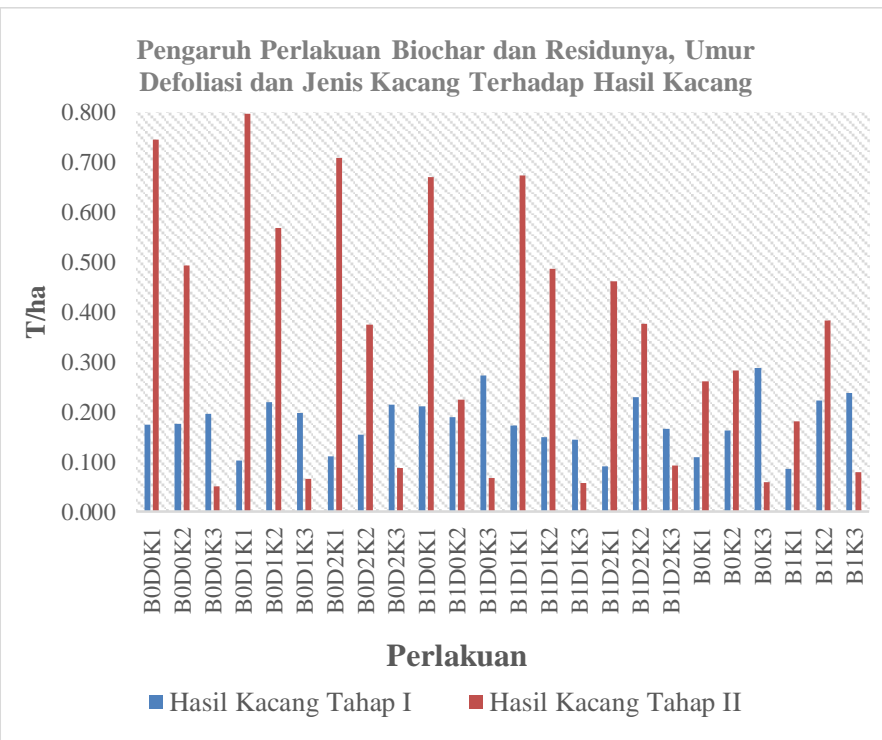

Gambar 3. Grafik Berat Biji Kacang ; B0: tanpa biochar, B1: Biochar sekam Padi D0: Tanpa Defoliasi, D1: Defoliasi daun jagung pada umur 35 hst, D2: Defoliasi daun jagung pada umur 75 hst, K1: jenis Kacang Vigna radiata L., K2: Jenis Kacang Vigna Umbellata L., K3: jenis kacang Phaseolus vulgaris $\mathrm{L}$.

Hasil kacang dalam (Gambar 3) menunjukkan bahwa tanaman kacang yang ditumpangsarikan dengan jagung menghasilkan berat biji lebih sedikit pada saat penanaman dengan menggunakan biochar dan meningkat pada saat tanaman kacang yang ditanam secara tumpangsari dengan menggunakan residu biochar. Rendahnya hasil kacang pada awal penggunaan biochar diakibatkan oleh berbagai factor misalnya kandungan ter yang terdapat pada biochar dan juga kemungkinan kelebihan nitrogen yang terdapat didalam tanah, sedangkan tingginya hasil pada penggunaan residu biochar sebagai akibat konversi cadangan hara yang tersimpan dalam tanah dan berasal dari sarasah tanaman dan bintil akar pada saat penanaman pertama. Kompetisi menimbulkan terjadinya penurunan unsur hara dan air didalam tanah serta berkurangnya intensitas cahaya yang sampai pada tanaman yang lebih pendek tajuknya.

Hal ini menjadi faktor pembatas pertumbuhan dan hasil tanaman yang menyebabkan penurunan hasil tanaman dalam tumpangsari. Tanaman kacang tipe tegak yang ditanam bersama-sama dengan jagung mengalami kehilangan hasil dibandingkan dengan monokulturnya dengan kisaran $-271,4 \%$ sampai $+39,1 \%$. Penurunan berat biji kacang $-271,4 \%$ menunjukkan kenaikan berat biji kacang dalam sistem tumpangsari sebesar $271,4 \%$ dari monokultur sedangkan kehilangan hasil sebesar $+39,1 \%$ menunjukkan penurunan berat biji kacang sebesar 39,1\% dalam sistem tumpangsari dari sistem monokultur. Jenis kacang Vigna radiata L. memberikan sumbangan penurunan hasil paling rendah yaitu berkisar antara $-1,6 \%$ sampai $-144,5 \%$ pada saat awal penggunaan biochar sedangkan pada saat penggunaan residu biochar kehilangan hasil berkisar $-170,8 \%$ sampai $-271,4 \%$. Jenis kacang Vigna umbellate L. memberikan sumbangan kehilangan hasil akibat tumpangsari 
sebesar $-34,3 \%$ sampai $+32,7 \%$ pada awal penggunaan biochar sedangkan pada saat penggunaan residu biochar berkisar $-101,5 \%$ sampai $+41,6 \%$. Jenis kacang Phaseolus vulgaris L. memberikan kehilangan hasil antara $-14,7 \%$ sampai $+39,1 \%$ pada awal penggunaan biochar dan $-49,2 \%$ sampai $+28,6 \%$ pada saat penggunaan residu biochar (Gambar 4.).

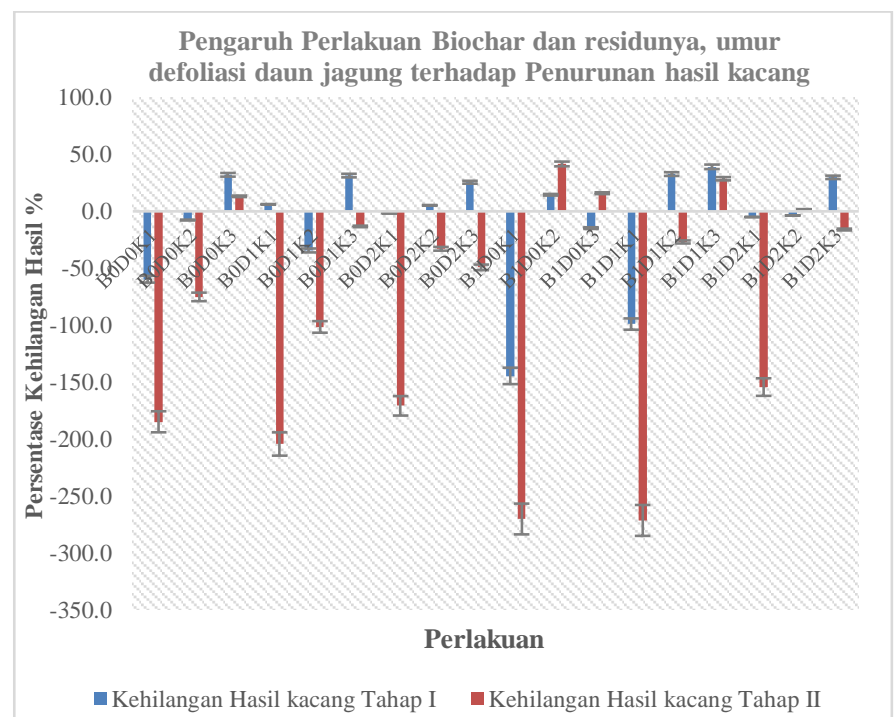

Gambar 4. Persentase Kehilangan Hasil Kacang Akibat Tumpangsari dengan Jagung ; B0: tanpa biochar, B1: Biochar sekam Padi, D0: Tanpa Defoliasi, D1: Defoliasi daun jagung pada umur 35 hst, D2: Defoliasi daun jagung pada umur 75 hst, K1: jenis Kacang Vigna radiata L., K2: Jenis Kacang Vigna umbellata L., K3: jenis kacang Phaseolus vulgaris $\mathrm{L}$.

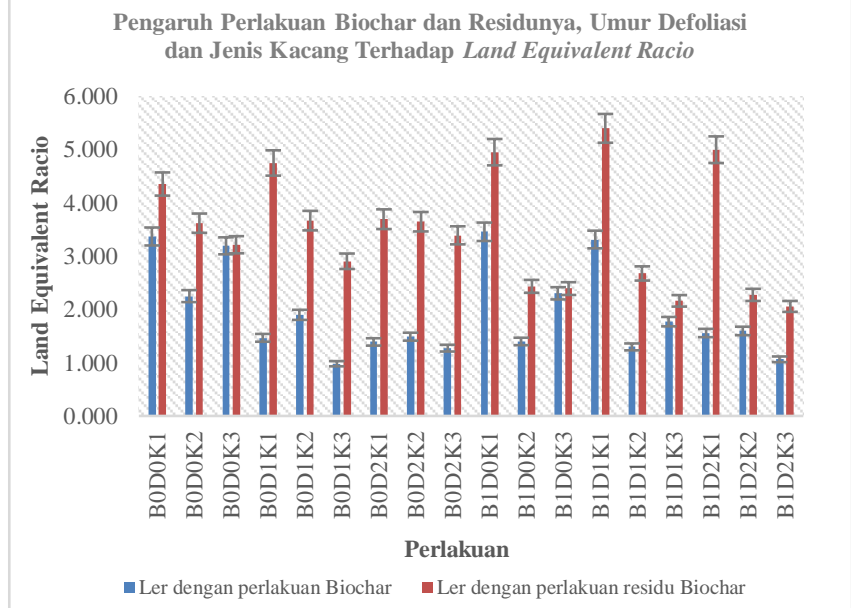

Gambar 5. Grafik Land Equivalent Racio ; B0: tanpa biochar, B1: Biochar sekam Padi, D0: Tanpa Defoliasi, D1: Defoliasi daun jagung pada umur 35 hst, D2: Defoliasi daun jagung pada umur 75 hst, K1: jenis Kacang Vigna radiata L., K2: Jenis Kacang Vigna umbellata L., K3: jenis kacang Phaseolus vulgaris L.

Hal ini senada dengan ungkapan Sundari et al., (2019) bahwa Kehilangan hasil akibat tumpangsari pada tanaman kacang kedelai berkisar $53,80 \%$ sampai $68,51 \%$ yang ditumpangsarikan dengan Jagung.

Hasil Pengamatan terhadap parameter Land Equivalent Racio (LER) menunjukkan bahwa terjadi interaksi antara perlakuan biochar dan residunya, umur defoliasi daun jagung, dan jenis kacang tipe tegak dalam tumpangsari jagung dan kacang. Hasil uji lanjut menunjukkan bahwa perlakuan penggunaan biochar, tanpa defoliasi daun jagung yang dikombinasikan dengan jenis kacang Vigna radiata L. menghasilkan nilai LER paling tinggi $(3,456)$ yang berbeda sangat nyata dengan kombinasi perlakuan lainnya, sedangkan pada uji penggunaan residu biochar menunjukkan bahwa penggunaan biochar, dengan umur defoliasi 35 hst dengan jenis kacang Vigna radiata L. menghasilkan nilai LER paling tinggi $(5,396)$ yang berbeda sangat nyata dengan perlakuan lainnya. Pada uji residu biochar menunjukkan adanya konsistensi bahwa tanaman jagung yang ditanam secara salome bersama jenis kacang vigna radiata $\mathrm{L}$. menghasilkan nilai LER paling baik dibandingkan dengan jenis kacang Vigna umbellata L. dan Pahaseolus vulgaris L. Alhassan et al., (2012), keuntungan tanaman dapat diukur dengan menghitung nilai land equivalent racio dalam sistem tanam tumpangsari dengan nilai LER $>1$.

Keuntungan tanaman dalam sitem tumpangsari antara tanaman jagung dengan tanaman kacang mungkin yang berasal dari sarasah dan bintil akar sehingga mampu meningkatkan pertumbuhan dan perkembangan tanaman sampai produksi dengan baik. Selain itu biochar yang ditambahkan kedalam tanah mampu mengikat unsur hara dengan baik serta menjadi rumah tinggal yang nyaman bagi bakteri didalam tanah sehingga kemampuan tanaman utama dan tanaman sisipan untuk berproduksi menjadi lebih tinggi (Gambar 5.)

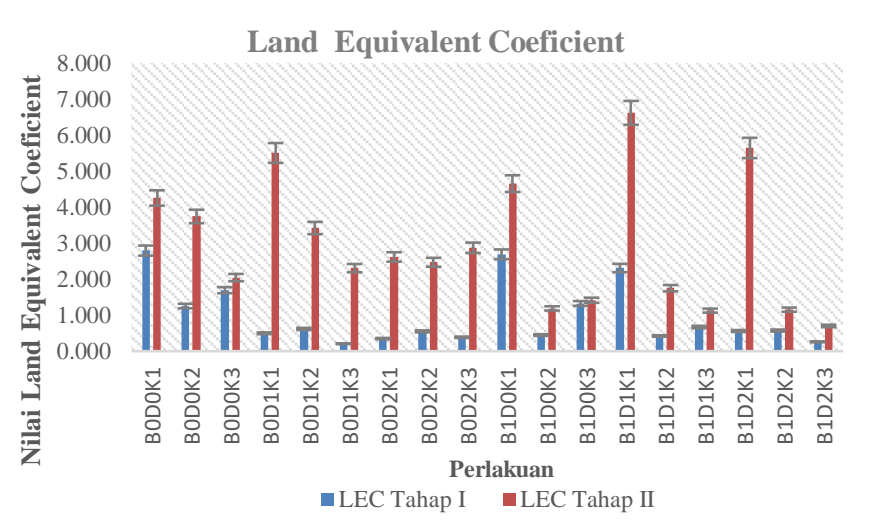

Gambar 6. Grafik Land Equivalent Coeficient ; B0: tanpa biochar, B1: Biochar sekam Padi, D0: Tanpa Defoliasi, D1: Defoliasi daun jagung pada umur 35 hst, D2: Defoliasi daun jagung pada umur 75 hst, K1: jenis Kacang Vigna radiata L., K2: Jenis Kacang Vigna Umbellata L., K3: jenis kacang Phaseolus vulgaris $\mathrm{L}$.

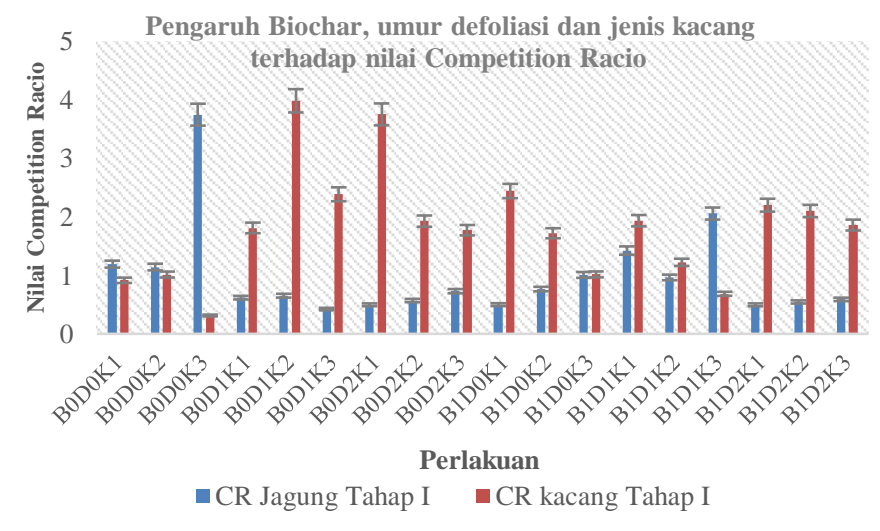

Gambar 7. Grafik Competition Racio Jagung dan Jenis Kacang dalam Tumpangsari ; B0: tanpa biochar, B1: Biochar sekam Padi, D0: Tanpa Defoliasi, D1: Defoliasi daun jagung pada umur 35 hst, D2: Defoliasi daun jagung pada umur 75 hst, K1: jenis Kacang Vigna radiata L., K2: Jenis Kacang Vigna Umbellata L., K3: jenis kacang Phaseolus vulgaris L.

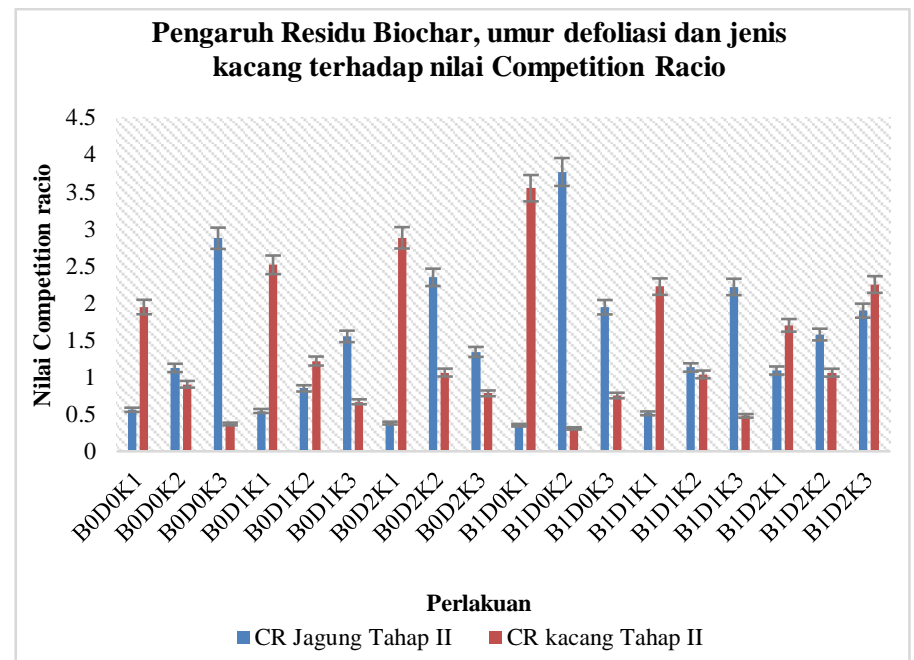

Gambar 8. Grafik Competition Racio Jagung dan Jenis Kacang dalam Tumpangsari ; B0: tanpa biochar, B1: Biochar sekam Padi, D0: Tanpa Defoliasi, D1: Defoliasi daun jagung pada umur 35 hst, D2: Defoliasi daun jagung pada umur 75 hst, K1: jenis Kacang Vigna radiata L., K2: Jenis Kacang Vigna Umbellata L., K3: jenis kacang Phaseolus vulgaris $\mathrm{L}$. 


\section{Actual Yield Loss}

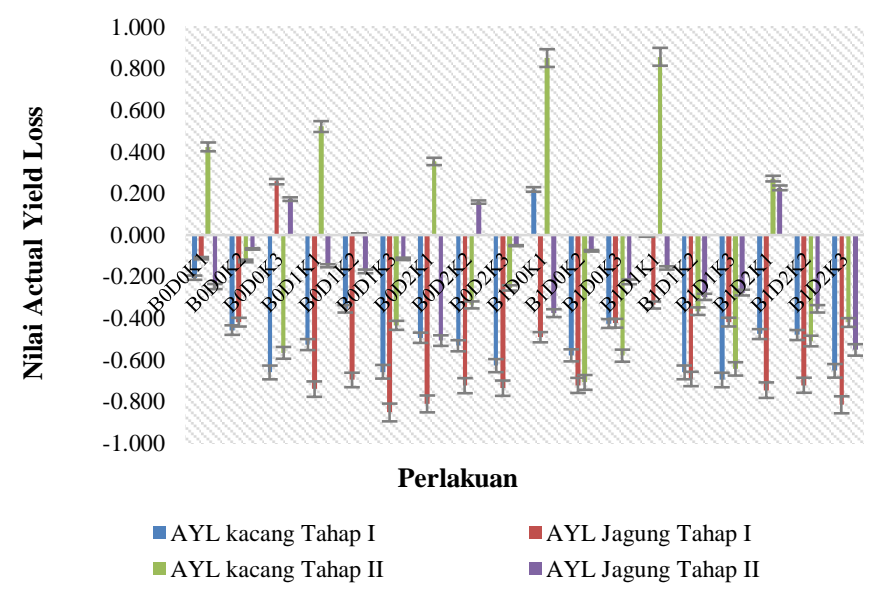

Gambar 9. Grafik Actual Yield Loss Tanaman dalam Tumpangsari ; B0: tanpa biochar, B1: Biochar sekam Padi, D0: Tanpa Defoliasi, D1: Defoliasi daun jagung pada umur 35 hst, D2: Defoliasi daun jagung pada umur 75 hst, Kl: jenis Kacang Vigna radiata L., K2: Jenis Kacang Vigna umbellata L., K3: jenis kacang Phaseolus vulgaris L

Hasil Penelitian menunjukkan bahwa terjadi interaksi antara perlakuan biochar dan residunya, umur defoliasi dan jenis kacang terhadap parameter Land Equivalent Coeficient (LEC). Kombinasi perlakuan tanpa biochar, tanpa defoliasi dengan jenis kacang Vigna radiata L. menghasilkan nilai LEC paling tinggi yang berbeda tidak nyata dengan penggunaan biochar, tanpa defoliasi dengan jenis kacang Vigna radiata $\mathrm{L}$. tetapi berbeda sangat nyata dengan perlakuan tanpa biochar, umur defoliasi daun jagung 35 hst dengan jenis kacang Phaseolus vulgaris L. Pada perlakuan residu biochar, umur defoliasi daun jagung 35 hst dengan jenis kacang Vigna radiata L. yang berbeda sangat nyata dengan perlakuan residu biochar, umur defoliasi daun jagung 75 hst dengan jenis kacang Phaseolus vulgaris L. Nilai LEC menunjukkan bahwa tumpangsari jagung dan jenis kacang yang ditanaman secara salome memberikan keuntungan karena nilai LEC >0,25.(Gambar 6.). Hal ini sesuai dengan laporan Hirpa (2014) bahwa dalam penanaman dua jenis tanaman yang berbeda diharapkan memiliki nilai coefisien produksi sebesar $25 \%$, yang berarti nilai LEC akan menguntungkan jika nilainya lebih besar dari 0,25 . Dalam penelitian ini nilai terendah dalam tumpangsari adalah perlakuan tanpa biochar, umur defoliasi daun jagung 35 hst dengan jenis kacang Phaseolus vulgaris L. yaitu sebesar 0,208 yang berarti tumpangsari mengalami kerugian, sedangkan pada saat penggunaan residu biochar semua perlakuan mengalami keuntungan karena nilai LEC > 0,25.

Hasil pengamatan terhadap parameter competition racio menunjukkan bahwa tidak terjadi interaksi antara perlakuan penggunaan biochar dan residunya, umur defoliasi daun jagung dan jenis kacang dalam tumpangsari terhadap tanaman jagung sedangkan pada tanaman kacang tidak terjadi interaksi. Jagung yang di tanam bersama-sama dengan kacang Phaseolus vulgaris L. tanpa perlakuan biochar dan tanpa defoliasi menghasilkan nilai kompetisi paling tinggi yang berbeda sangat nyata dengan kombinasi perlakuan lainnya sedangkan tanaman kacang yang ditanam bersama-sama dengan jagung tidak terjadi beda nyata. Gambar 7 dan Gambar 8 menunjukkan bahwa tanaman kacang lebih berkompetisi dibandingkan dengan tanaman jagung, namun pada beberapa kombinasi perlakuan menunjukkan adanya kompetisi yang kuat oleh jagung yang ditanam bersama-sama dengan jenis kacang Phaseolus vulgaris $\mathrm{L}$, pada awal penggunaan biochar dan pada penggunaan residu biochar pada tanaman jagung yang ditanam bersama-sama dengan Phaseolus vulgaris L. dan Vigna umbellata $\mathrm{L}$.

Hasil Pengamatan terhadap Actual yield loss menunjukkan bahwa terjadi interaksi antara perlakuan penggunaan biochar, umur defoliasi dan jenis kacang dalam tumpangsari Salome pada pengamatan tahap I, sedangkan pada tahap II tidak terjadi interaksi. Nilai Actual yield loss jagung tahap I paling tinggi sebesar -0,853 yang terjadi pada kombinasi perlakuan tanpa biochar, umur defoliasi 35 HST yang ditumpangsarikan dengan jenis kacang Phaseolus vulgaris L, yang mengakibatkan kerugian hasil jagung sebesar 85,3\% dan berbeda sangat nyata dengan kombinasi perlakuan tanpa biochar, tanpa defoliasi yang ditumpangsarikan dengan jenis kacang Phaseolus vulgaris L yang menghasilkan nilai Actual yield loss sebesar 0,257 yang mengakibatkan penambahan keuntungan hasil jagung sebesar 25,7\%. Nilai Actual yield loss tanaman kacang pengamatan tahap I paling tinggi sebesar $-0,697$ pada kombinasi perlakuan penggunaan biochar, umur defoliasi 35 HST dengan jenis kacang Vigna umbellata L. yang mengakibatkan kerugian hasil kacang sebesar $69,7 \%$ dalam tumpangsari dan berbeda sangat nyata dengan kombinasi perlakuan penggunaan biochar, tanpa defoliasi dengan jenis kacang Vigna radiata $\mathrm{L}$ sebesar 0,219 yang mengakibatkan penambahan keuntungan hasil kacang sebesar $21,9 \%$.
Nilai Actual yield loss jagung tahap II paling tinggi sebesar -0,552 yang terjadi pada kombinasi perlakuan penggunaan residu biochar, umur defoliasi 75 HST yang ditumpangsarikan dengan jenis kacang Phaseolus vulgaris L, yang mengakibatkan kerugian hasil jagung sebesar 55,2\% dan berbeda sangat nyata dengan kombinasi perlakuan penggunaan residu biochar, umur defoliasi 75 HST yang ditumpangsarikan dengan jenis kacang Vigna radiata L yang menghasilkan nilai Actual yield loss sebesar 0,227 yang mengakibatkan penambahan keuntungan hasil jagung sebesar 22,7 \%. Nilai Actual yield loss tanaman kacang pengamatan tahap II paling tinggi sebesar 0,851 pada kombinasi perlakuan penggunaan residu biochar, tanpa defoliasi dengan jenis kacang Vigna radiata L. yang mengakibatkan penambahan keuntungan hasil kacang sebesar 85,1 \% dalam tumpangsari dan berbeda sangat nyata dengan kombinasi perlakuan penggunaan residu biochar, tanpa defoliasi dengan jenis kacang Vigna umbellata $L$ sebesar -0,708 yang mengakibatkan kerugian hasil kacang sebesar 70,8 \% (data tersaji dalam Gambar 9).

\section{Simpulan}

Hasil penelitian tahap I menunjukkan bahwa berat biji tanaman jagung tertinggi dihasilkan kombinasi perlakuan tanpa biochar dengan umur defoliasi daun jagung 35 hst pada sistem monokultur sedangkan pada sistem tumpangsari dihasilkan oleh kombinasi perlakuan biochar, umur defoliasi daun jagung 35 hst pada jenis kacang Vigna radiata L., Hasil penelitian tahap II menunjukkan bahwa bahwa kombinasi perlakuan penggunaan residu biochar, umur defoliasi daun jagung 75 hst menghasilkan berat biji jagung tertinggi yang ditanam dengan sistem tumpangsari dengan jenis kacang hijau. Hasil penelitian tahap I menunjukkan bahwa Berat biji tanaman kacang tertinggi dihasilkan oleh kombinasi perlakuan tanpa biochar dengan jenis kacang Phaseolus vulgaris $\mathrm{L}$. pada sistem monokultur, sedangkan pada sistem tumpangsari dihasilkan oleh kombinasi perlakuan penggunaan biochar tanpa defoliasi daun jagung dengan jenis kacang Phaseolus vulgaris L.

Hasil penelitian tahap II menunjukkan bahwa kombinasi perlakuan penggunaan tanpa residu biochar, umur defoliasi daun jagung 35 hst dengan jenis kacang hijau paling tinggi pada sistem tanam tumpangsari.Hasil jagung pada sistem tumpangsari Salome diawal penggunaan biochar mengalami penurunan dibandingkan control tetapi meningkat kembali pada saat penggunaan residu biochar, umur defoliasi daun jagung 35 hst lebih baik dibandingkan tanpa defoliasi, semua jenis kacang cocok untuk ditaman dengan sistem tumpangsari salome. Jenis kacang Vigna radiata L. dan Vigna umbellata L. lebih cocok ditanam dengan sistem tumpangsari salome dengan jagung pada awal penggunaan biochar maupun pasa saat penggunaan residu biochar. Hasil penelitian secara keseluruhan menguntungkan karena nilai Land Equivalent Racio $>1$, Land Equivalent Coeficient $>0,25$.

\section{Pustaka}

Alhassan G.A., B.A. Kalu., O.M. Egbe., 2012., Influence of planting densities on the performance of intercropped bambara groundnut with cowpea in Makurdi, Benue state, Nigeria., International Journal of Development and Sustainability Volume 1 Number 3: Pages 860-879

Banik, P. 1996. Evaluation of Wheat (Triticum aestivum) and Legume Intercropping Under $1: 1$ and 2:1 Row-replacement Series System., Journal of Agronomi and crop science., volume 176(5)

Bau Demetriana Bele., 2017., Pengaruh waktu perendaman dan takaran biochar dalam urin sapi terhadap pertumbuhan jagung dalam tumpangsari Salome dengan kacang hijau., Skripsi., universitas Timor., Kefamenanu.

Beets W.C., 1982. Multiple Cropping and Tropical Farming System. Chicago: Gower Publ Co. Chicago.

Berek Arnoldus Klau., Syprianus Ceunfin., Roberto I.C.O Taolin., Eduardus Yosef Neonbeni., \& Maksimus Johanes Seran., 2017., Efek Biochar Dan Teh Kompos Terhadap Pertumbuhan Dan Hasil Selada Darat (Lactuca Sativa L) Di Tanah Vertisol Semi arid., J.Floratek 12(2): 101-114

Ceunfin S., 2018., Efek Model Tumpangsari dan Pengaturan Barisan Jagung terhadap Evaluasi Keuntungan Hasil Jagung dan Kacang Nasi Kultivar Lokal Timor dalam Tumpangsari., Savana Cendana 3 (2) $18-20$

Ceunfin S., Humoen M.U., Boyfala S.M.A., Seran A.H., \& Lelang A., 2018 Pengaruh Model Defoliasi Daun Jagung dan Jumlah Benih terhadap Hasil Jagung dan Kacang Nasi pada SistemTumpangsari Salome (KearifanLokal Timor)., Savana Cendana 3(1) 8-10

Gai X, Wang H, Liu J, Zhai L, Liu S, Ren T, Liu H. 2014. Effects of Feedstock and Pyrolysis Temperature on Biochar Adsorption of Ammonium and Nitrate. PLoS ONE 9:2-19.

GlaserB., Haumeier L., Guggenberger G., \&Zech W., 2001., The 'Terra Preta' Phenomenon: A ModelForSustainable Agriculture In The Humidtropics. Natur wissens chaften Vol 88, 37-4.

Humoen M.U., 2017., Pengaruh waktu perendaman dan takaran biochar dalam urin sapi terhadap pertumbuhan kacang hijau dalam tumpangsari Salome dengan jagung., Skripsi., universitas Timor., Kefamenanu. 
Hopkins., 1995. Introduction to Plant Physiology. John Willey and Sons Inc, Singapore

Indradewa D., Sastrowinoto S., Notohadisuwarno S., \& Prabowo H., 2004., Metabolisme Nitrogen Pada Tanaman Kedelai Yang Mendapat Genangan Dalam Parit., 1mu Pertanian Vol. 11 No. 2: 68-75

Keift J.A.M., 2007., Farmers Use of Sesbania Grandiflora Intensify Swidden Agriculture in Nort Central Timor, Indonesia., Program Leaders of Agriculture Disester Management and Conflict Recovery, CARE, International Indonesia.

Khodijah NS., Kusmiadi R., \& Sartika S., 2014., Optimalisasi Produksi Kacang Tanah Dan Jagung Pada Pola Tanam Tumpangsari dengan perlakuan defoliasi jagung., Enviagro, Jurnal Pertanian dan Lingkungan Vol.7 No. 2

Levis, L. R., K. Sukesi, Sugiyanto \& Y. Yuliati. 2017. Farmers Behaviour Regarding Food Security By Practicing The 'Salome' Farming System As Local Wisdom In West Timor, East Nusa Tenggara Province, Indonesia. Tropical and Subtropical Agroecosystems, 20(2017): $231-236$.

Niswati A., Taisa R., \& Suryani M., 2018., Peningkatan Respirasi Tanah dan Pertumbuhan Tanaman Jagung Akibat Residu Biochar Pada Top Soil Dan Sub Soil Tanah Ultisols., Proseding Forum Komunikasi Perguruan Tinggi Pertanian Indonesia (FKPTPI) 2018 Universitas Syiah Kuala Banda Aceh

Neo F. X \& Ceunfin S., 2018., Pengaruh Model Tumpangsari dan Pengaturan Jarak Tanam Kacang Nasi (Vigna angularis L.) Kultivar Lokal terhadap Pertumbuhan dan Hasil Tanaman Jagung (Zea mays L.).,Savana Cendana 3(1) 14-17

Novak J.M., Lima I, Xing B, Gaskin JW, Steiner C, Das KC, Ahmedna MA, Rehrah D, Watts DW, Busscher WJ, and Schomberg H. 2009. Characterization of designer biochar produced at different temperatures and their effects on a loamy sand. Annal. Environ. Sci. 3:195-206.

Palaniappan. 1985. Cropping system in the Tropic: Prinsiples and Management. Coimbataro: Wiley Eastern Limited and Tamil Nadu Agricultural University.

Rosidi A., Mulyati \& Sukartono., 2016., Evaluasi Pengaruh Residu Biochar dan Dosis Nitrogen Terhadap Pertumbuhan dan Hasil Kedelai (Glycine max. L. merill.) pada Tanah Bertekstur Lempung Berpasir (Sandy Loam)., Crop Agro Vol 9 No 1: 1-8

Saba Agu, Yakobus P.E. 2017. Desain Model Pengelolaan Lahan Kering Dataran Tinggi Berbasis Berbasis Agroforestri Tradisional Di Pulau Timor. Tesis UGM. Yogyakarta.

Sarkhot D.V., Ghezzehei TA, and Berhe AA. 2013. Effectiveness of biochar for sorption of ammonium and phosphate from dairy effluent. $\mathrm{J}$. Environ. Qual. 42:1545-1554

Sanit E \& Nubatonis A., 2018., Analisis Pendapatan Usaha tani Tumpangsari Palawija di Desa Letneo Selatan dan Desa Unini Kecamatan Insana Barat., Agrimor 3 (2) 30-33

Suchri Amin., 2010. Dampak Penataan Baris Tanam dan Defoliasi Daun Jagung terhadap hasil jagung (Varietas Tambin), pertumbuhan dan hasil kacang tanah (varietas Jerafah) Dalam Sistem Tumpangsari. Agrovigor Volume 3 No 1 ISSN 1979-5777.

Sundari Titik., Siti Mutmaidah, Yuliantoro Baliadi., 2019., Keunggulan Kompetitif Agronomis dan Ekonomis Lima Belas Genotipe Kedelai pada Tumpangsari dengan Jagung., Buletin Palawija VOL. 17 No. 1

Surtinah., 2005. Hubungan Pemangkasan Organ bagian Atas Tanaman Jagung (Zea mays, L) dan Dosis Urea terhadap Pengisian Biji. Jurnal Ilmiah Pertanian Vol. 1 No. 2

Steinbeiss S., Gleixner G., \& Antonietti, M. 2009., Effect Of Biochar Amendment On Soil Carbon Balance And Soil Microbial Activity. Journal Soil Biolology and Biochemistry vol 41:13011310

Taghizadeh-Toosi A, Clough TJ, Sherlock RR, \& Condron LM 2012. Biochar adsorbed ammonia is bioavailable. Plant Soil 350:57-69

Uchimiya M., Cantrell K.B., Hunt P.G., Novak J.M., and Chang S., 2012. Retention of heavy metals in a Typic Kandiudult amended with different manure-based biochars. J. Environ. Qual. 41:11381149.

Ventura, M, Sorrenti G, Panzacchi P, George E, and Tonon G. 2013. Biochar reduces short-term nitrate leaching from A horizon in an Apple Orchard. J. Environ. Qual. 42:76-82.

Yilmaz Şaban., Ali ÖZEL., Mehmet ATAK., \& Mustafa ERAYMAN., 20015., Effects of seeding rates on competition indices of barley and vetch intercropping systems in the Eastern Mediterranean., Turkish Journal of Agriculture and Forestry., 39: 135-143

Wijaya A.B., Mulyati \& Dahlan M. 2018. Uji Pengaruh Residu Biochar Dan Pupuk NPK Terhadap Ketersediaan Hara Kalium, Pertumbuhan Dan Hasil Tanaman Selada (Lactuca sativa L.)., jurnal Crop Agro. 